DOI: 10.4274/jarem.galenos.2020.3425

J Acad Res Med 2020;10(3):208-13

\title{
Urethral Stenosis and Urethroplasty in Male Elderly
}

\author{
(1) Ali Ayyıldız
}

Adıyaman University Faculty of Medicine, Department of Urology, Adıyaman, Turkey

Cite this article as: Ayyıldız A. Urethral Stenosis and Urethroplasty in Male Elderly. J Acad Res Med 2020;10(3):208-13

\begin{abstract}
Old age is defined as age 65 and older according to the World Health Organization. Urethral stenosis is a group of diseases with high morbidity in male society. Patients undergo surgery many times. In the elderly population, urethral stenosis develops especially secondary to diseases caused by aging. Stenosis occurs due to reasons such as benign prostatic enlargement, endoscopic urological manuplations, pelvic radiation therapy for rectal or prostate cancer, insertion of a probe. It is believed that reactions that develop at the cellular level due to hypogonadism in the elderly and the disadvantages caused by comorbidity, nutritional problems affect the course of urethral stenosis and the results of urethroplasty. Wound-related problems occur more often in the elderly. Researchers who share their urethroplasty experience with us express that all urethroplasty methods applied in young people can also be applied in the elderly population. But all interventions that will be made in the elderly population must be decided and implemented in detail. In this review, urethral stenosis, etiology, wound, elderly urethra, hypogonadism and their treatment were reviewed in the elderly. The number of published articles associated with elderly urethroplasty is quite small. There is a need for well-designed specialized research involving this age group.
\end{abstract}

Keywords: Male elderly, urethral stenosis, urethroplasty, hypogonadism, wound healing

\section{INTRODUCTION}

Unfortunately, there are several published articles when we look at the stenosis and treatments of the urethra involving the elderly population. Studies involving urethroplasty and its consequences in older people are almost non-existent. In most cases, the article on urethral stenosis and its treatments contains information about all age groups and the results of the study. In this review, an overview of old age, etiology, treatment methods and results, elderly wound and wound healing were reviewed in elderly patients with urethroplasty due to urethral stenosis. Isolated studies of urethral stenosis and urethroplasty are needed in the group of 65 years and older.

\section{Elderly}

According to the World Health Organization, age 65 and older is considered chronologically elderly. Old age is a natural and inevitable period of life, such as childhood, youth, adulthood, in which the interaction between genetic structure and the environment is observed at the highest level, physiological and spiritual changes occur, with complex aspects, seen in all living things (1). Even if each person is chronologically the same age, their physiology, biochemical and genetic structure are different, so they also react differently to diseases and treatments.

\section{Overview}

Chronological, biological and physiological ages should be considered while evaluating urethral injury and treatment in old age. Note the difference between chronological and biological aging. Accordingly, it has been stated that different organs and tissues in a person's body may have different biological aging rates compared to that person's chronological age, as well as different

ORCID ID of the author: A.A. 0000-0003-3724-2516. 
individuals of the same chronological age may have very different biological aging rates. We act according to chronological age in our studies and statistical evaluations. Although they have the same chronological age, it should be assumed that the biological and physiological characters are different, which will have a positive or negative impact on wound healing.

Biological aging is the structural and functional change of the body during the development process. Our general way of life has an effect on the aging of our cells. With aging, continuous and inevitable decreases in productivity and physiological processes are observed. This is called physiological aging. Body composition, cardiovascular system, kidneys, digestive system, liver, brain, nervous system, lungs and functional deficiencies occur in the endocrine system (1).

Mortality in old age has decreased in some countries, and according to data from more than 30 developed countries, the probability of survival between the ages of $80-90$ is about $37 \%$ on average. In some countries, the probability of survival exceeds $50 \%$ at the age of $80-90$ (2).

Urethral stenosis disease is common and costly, observed in $0.6 \%$ of men and is stated to have created an economic cost of over $\$ 200$ million in the United States in 2000. Advances in technology have increased endoscopic surgeries, and the associated risk of developing urethral stenosis has also increased. The epidemiology of stenosis disease is well defined, but the underlying basic pathophysiological mechanisms are still not well understood (3). Liu et al. (4), in the urethral stenosis series of 262 patients, reported the proportion of older people over 65 years of age as $24.8 \%$. One in every four patients appears to be elderly (4).

\section{Aged Urethra}

Testosterone is important in the development of the urethra, for the integrity and function of the smooth muscles of the corpora cavernosa. Due to a decrease in testosterone levels in old age, there is a decrease in androgen receptors and periurethral vascularity in the urethra (5). A study identified a significant increase in urethral atrophy risk and artifical sphincter erosion due to a decrease in serum testosterone (6). For this reason, it has been suggested that there may be an increase in urethral stenosis and an inability to achieve treatment results due to a decrease in androgen, which develops secondary in the elderly (3).

Aging and wound healing play an important role in the microlevel structure of the urethra, and extracellular matrixes are necessary in the healing and proliferation process, as in all tissues (7). Matrix metalloprotein enzymes (MMP) increase with aging (8). It has been stated that even the urethral plaques of hypospadias in childhood show significant age-related structural changes, and these changes may play a role in urethral healing after hypospadias repair (9). The MMP enzyme family plays a key role in embryonic development, organ morphogenesis, ovulation, embryo implantation, wound healing, angiogenesis and apoptosis (8). Extracellular matrix and MMPs affect all tissues and reactions in old age. Experimental studies on this subject are continuing in urethral strictures (10).

\section{Etiology and Stenosis Localization}

Some of the most common etiologies of stenoses are lichen sclerosis, trauma, iatrogenic and infections $(11,12)$. Sexually transmitted diseases, which are common in past times, today cause less urethral stenosis after new medical treatments. For this reason, the etiology of urethral stenosis also changed in old age (13). Pelvic radiation therapy is also a factor due to cancer treatments in old age (3). Urethral stenosis of iatrogenic or idiopathic origin are most common in industrialized countries (14). Currently, the most common cause of panurethral stenosis is genital lichen sclerosis (15). When all stenosis are evaluated, iatrogenic causes constitute almost half of the cases (13). Stenoses are most often seen in elderly patients secondary to urological instrumentation (3). Because a large number of translansurethral resections are performed due to prostate diseases and bladder tumors (16-18). Santucci et al. (17) stated that etiological factors developed due to $43 \%$ iatrogenic, $14 \%$ trauma, $14 \%$ prolonged catheter duration, $9 \%$ radiation therapy, $7 \%$ infection, $7 \%$ previous urethroplasty, and $3 \%$ radical prostatectomy, respectively, in their series of 70 patients over the age of 65 . Schwetner et al. (13) identified the cause of stenoses as $26 \%$ iatrogenic, $9.5 \%$ trauma, $45 \%$ instrumentation, $12 \%$ catheter, and $7 \%$ infection in their study involving 32 patients in the same age group. As it is seen, stenoses that develop secondary to endoscopic prostate and bladder operations in old age take the first place. Although it was previously known that the success rates of endoscopic treatment with internal urethrotomia were poor, it was considered the first option in practice, as limited life expectancy was considered in elderly patients (19). Although life expectancy has increased, when we look at population-based studies, most clinicians still use internal urethrotomia as the first option in our country for various reasons, although it varies from country to country $(2,17,20)$. However, open urethroplasty has the best results $(13,15,17,21-25)$.

Looking at the location of the stenosis, bulbar region is observed in the first place in the elderly $(13,18)$. Spencer et al. $(3)$, in their study investigating the relationship between hypogonadism and urethral stenosis, defined the most common place of stenosis in the two different groups as 53\% and $57 \%$ at the bulbomembranous level. However, these groups include not only the elderly but also those under 65 (3). Schwentner et al. (13) confirmed that the bulbar region took the first place in terms of stenosis localization, similar to other researchers, in their series of 42 patients, but unlike other authors, they explained a high rate of $64 \%$.

\section{Comorbidity}

As we know, comorbid diseases increase in old age (26). Therefore, considering the co-diseases associated with urethral stenosis, it is observed that diabetes, obesity and hypertension are most common, respectively, while in cases of comorbidity, the failure of urethroplasty increases. Age progression increases 
the likelihood of strictures. The occurrence of stenosis and risk of treatment failure are associated with obesity $(27,28)$. It is not known exactly how co-observation of comorbid diseases with old age contributes to urethral stenosis, surgery and recovery or failure of treatment. Advanced studies are needed on this issue. In general, comorbid diseases leave damage at the level of tissues and cells. It is possible that the presence of cellular or tissue damage secondary to the urethra due to these comorbidities will affect the post-urethral surgery.

\section{Testosterone and Hypogonadism}

Age, diabetes and obesity are associated with hypoandrogenism (HA) $(3,28)$. Testosterone is important in urethral development and cavernosal smooth integrity and function (29). HA involves a decrease in urethral androgen-related receptors and periurethral vascularity (5). Also, low serum testosterone levels increase the risk of urethral atrophy and artificial sphincter erosion (6). It is not unreasonable to assume this link, but it is still difficult to establish a clear link between $\mathrm{HA}$ and urethral stricture and treatment failure.

Testosterone has multiple actions in the body, such as sexual differentiation and its effects on reproduction, muscle, bone, hematopoiesis, and behavior (30). Measurement of testosterone has been included in biochemical uncertainty assessments (31). As we know, testosterone is already declining in aging men, and it remains unclear at what point this decline is clinically significant. There are different attempts in relation to the topic to describe the status of low testosterone in aging men $(3,30)$. It is not known exactly how testosterone or other androgenic receptors play a role in both urethra healing and other tissue and organ healing. Low testosterone due to secondary hypogonadism is due to insufficient gonadotropins, as most seniors have developed testicular failure. A study by Corona and Maggi (32) revealed concomitant metabolic diseases in about $90 \%$ of men with secondary hypogonadism. These diseases have been observed in more than $70 \%$ of men. All systems are affected in old age.

Androgen-dependent processes include not only the urethra, but also spongious tissue, and the vascular environment in spongious tissue. In case of androgen deficiency, the development of degeneration, atrophy and fibrosis in vascular and spongious tissue will contribute to the physiology of urethral stenosis. Moreover, in the case of hypogonadism, there is an increase in the level of systemically circulating proinflammatory cytokines (3). Suppression of systemic inflammatory responses was found when testosterone was administered externally to patients with hypogonadism $(33,34)$.

\section{Treatments}

Before planning treatment, the urethra must be fully evaluated. For this purpose, retrograde urethrography, combined cystouretrography, urethroscopy should be performed first. Alpha blockers, which are started a few days before combined cystouretrography or 5-6 hours in advance, will increase the opening of the bladder neck, so an optimal image can be achieved. Endoscopy should then be planned both antegrad and retrograde depending on the condition of the stenosis.

In general, non-invasive techniques such as urethral dilation were abused in the past, and then internal urethrotomyr was presented as a definitive solution to the problem and became common without dilation and dilation. It was the first choice of doctors and patients, especially in short strictures. However, the problems and failure increased (20). Endoscopic treatment methods, which were widely used in the treatment of stenosis in the past, should be reviewed in terms of optimum treatment, since their success rates are low and they are not effective in long stenoses. Follow-up results of internal urethrotomy are poor (17). Nowadays, internal urethrotomy is recommended twice, only in appropriate cases $(16,20)$.

A decrease in mortality in the elderly population today and a long life span have emerged as an unprecedented and unexpected situation. Therefore, the concept of urethral stenosis treatment had to be reconsidered in this population. From this point of view, it was reported that open urethroplasty should be raised as a first and valuable option in advanced older people over the age of $75(35,36)$. Nowadays, the effectiveness of urethroplasty with a low complication rate has been proven with good surgical practices $(37,38)$. Internal urethrotomy or dilatation are unacceptable procedures with failure rates of $50 \%$ in the first application and $100 \%$ in the second $(17,20)$. Despite the aging population, especially in western countries, very few articles have been published about which open procedures can be applied in stenosis treatments $(13,17)$. Santucci et al. (17) first published a study in 2004 in which they showed open urethroplasty results, complication and failure rates in the elderly group. This was the first article we could find in PubMed's scan. After a long time, in 2010, Schwentner et al. (13) shared the results of onlay skin graft, in which they performed open urethroplasty in elderly patients. According to our information, no further studies have been published on PubMed until 2020.

A gold standard treatment method, which we can say that the following technique is suitable for strictures, has not been defined yet. However, a tension-free anastomosis, spongiofibrosis, and the length of the stenosis are effective in determining the open urethroplasty method (35-38). Although buccal mucosa graft applications are most popular in young patients, there are concerns that oral factors such as poor oral hygiene, leukoplakia and dental prosthesis will disrupt the quality of the graft in older patients $(13,39,40)$. Submucosal fibrosis may occur in those with long-term tobacco use and grafts taken due to poor oral hygiene (41-43). In panuretroplasties, although complication rates are minimal even when oral mucosa grafts are used, this rate is $17.5 \%$. In this study, Schwentner et al. (13) showed that dorsay onlay techniques are effective and reliable in older people. There are no very detailed studies on the results of graft intake in the elderly (14). The only treatment option for long stenoses or panurethral stenoses is the application of urethroplasty using alternative methods of operation. Considering etiological factors, the characteristics of 
Barbagli et al. (49) found that both skin and buccal mucosa grafts were more successful than flap procedures (26). Posteriorly applied grafts can make urethroplasty suitable in elderly patients, with the advantage of being fed with the abundant blood inherent in the corpora cavernosa $(14,26)$. In addition, mechanical support of cavernosal tissue and dorsal onlay graft urethroplasty have been shown to provide long-term durability $(59,60)$. Persistent perineal urethrostomy may be an option in complex cases with severe strictures, where urethroplasty has failed several times. Santucci et al. (17) applied this method in 4 of 70 patients (20).

Ventral interventions in accordance with the omega structure of the external sphincter are an appropriate approach to reduce incontinence in posterior urethral strictures. Despite this, the patient should be informed about dorsal interventions. Tissue engineering has also been applied in some centers recently. Urethra tissue produced in laboratories is used in surgeries (61). However, the researchers state that the tissue-engineered urethral tissue is very thin and requires careful surgery because of the high risk of tearing during surgery.

The Turkish Society of Urology and the Turkish Academy of Urology have published guidelines for diagnosis, treatment and followup protocols in urethral strictures. In this guide, the diagnosis, pathophysiology, treatment methods and follow-up protocols of urethral stenosis are summarized under the guidance of the American Urological Association and the European Urological Association guidelines. It is possible to find methods that can also be applied to older patients in the same manual and apply them in surgery, especially with more pictures and protocols to give them the opportunity to quickly browse in daily practice (62).

\section{Elderly Wound and Healing}

A wound can occur spontaneously, as well as iatrogenically, including operations. Surgeons accelerate the healing of surgical wounds thanks to the methods they have developed. However, factors such as patients' physical condition, tissue and immune systems, nutritional status and comorbidity due to their chronological, biological, physiological aging are effective in wound healing. In an epidemiological study that lasted 5 years with chronic wounds and examined 1158 wounds, it was reported that the wound closure time was significantly slower in older patients than in younger patients, and the wound closure time slowed after the age of 60 (63).

In wound healing; There are hemostasis, inflammation, proliferation and maturation phases. All of these phases are affected in the elderly. With increasing age, the number of platelets adhering to the injured endothelium and the release of growth factors increase (64). In elderly individuals, the components involved in inflammation reach the wound later, and therefore the inflammatory response is delayed. In addition, capillary permeability at the injury site decreases, so there is a slowdown in the transition of leukocytes to the wound site. In experiments with older animals, it was found that the number of phagocytic macrophages and the phagocytic skills of macrophages and the production of elderly patients due to their higher rate of unsuccessful results. 
growth factors secreted by macrophages decreased with age (65). The response to hypoxia in the elderly is also impaired. With increased age, there is a decrease in proliferative responses of keratinocytes, fibroblasts and vascular endothelial cells. There are also regressions in collagen synthesis and angiogenesis process. All these negatives can lead to delays in healing the wound and failure to close the wound (66). With age, the strength of the tissue to resist tears decreases, and this is explained by the decreasing collagen fibers. In elderly individuals, the strength of the wound is gained in a longer time than the young people and the strength of the wound obtained is weaker than the young individuals. Common comorbid diseases facilitate wound formation and make wound healing difficult. Factors such as reduced levels of hormones, nutritional problems, stress, obesity and multiple drug use also negatively affect wound healing. Among the factors affecting wound healing in the elderly; nutritional problems that may accompany chronic diseases, dermis thickness of the skin, protection and immune response against microorganisms, serum albumin level, collagen production, pressure and feel sensations, loss of tissue elasticity, decrease in partial oxygen pressures due to respiratory problems and tissue oxygen deficiency (64-67).

\section{CONCLUSION}

Although comorbid diseases increase in old age, mostly diabetes and cardiovascular diseases, nutritional disorders, decrease in androgen amount and hypogonadism, development of urethral atrophy, delays in wound healing, the results of urethral stricture treatment and urethroplasty application are satisfactory. Life expectancy has increased in most countries nowadays. For this reason, open urethroplasties should replace optical internal urethrotomy, which has been introduced as a treatment option with low success rates. There is no data except for a few published articles on this subject. There is a need for projects and scientific studies targeting the elderly group in order to develop clearer and scientific attitudes.

Peer-review: Internally peer-reviewed.

Financial Disclosure: The author declared that this study has received no financial support.

\section{REFERENCES}

1. Yerli G. Yaşııık dönemi özellikleri ve yaşlılara yönelik sosyal hizmetler. Uluslararası Sosyal Araştırmalar Derg 2017; 10: 1278-87.

2. Christensen K, Doblhammer G, Rau R, Vaupel JW. Ageing populations: the challenges ahead. Lancet 2009; 374: 1196-208.

3. Spencer J, Mahon J, Daugherty M, Chang-Kit L, Blakely S, McCullough $A$, et al. Hypoandrogenism is prevalent in males with urethral stricture disease and is associated with longer strictures. Urology 2018; 114: 21823.

4. Liu JS, Dong C, Gonzalez CM. Risk factors and timing of early stricture recurrence after urethroplasty. Urology 2016; 95: 205-7.

5. Hofer MD, Kapur P, Cordon BH, Hamoun F, Russell D, Scott JM, et al. Low testosterone levels result in decreased periurethral vascularity via an androgen receptor-mediated process: pilot study in urethral stricture tissue. Urology 2017; 105: 175-80.

6. Hofer MD, Morey AF, Sheth K, Tausch TJ, Siegel J, Cordon Bh, et al. Low Serum Testosterone Level Predisposes to Artificial Urinary Sphincter Cuff Erosion. Urology 2016; 97: 245-9.
7. Üçgül I, Aras S, Elibüyük U. Ekstraselüler matris yapısı ve görevleri. Uludağ Üniv Müh Fak Derg 2018; 23: 295-310.

8. Uzun ML. Demirezer Ö. Cilt yaşlanması ve matriks metalloproteinaz enzimlerinin yaşlanma üzerine etkileri. J Lit Pharm Sci 2019; 8: 206-13.

9. da Silva EA, de Marins RL, Rondon A, Damiao R. Age-related structural changes of the urethral plate in hypospadias. J Pediatr Urol 2013; 9: 115560.

10. Guzman-Esquivel J, Delgado-Enciso I, Baltazar-Rodriguez LM, RodriguezHernandez A, Juarez-Pineda U, Melnikov V. Metalloproteinase-1 usefulness in urethral stricture treatment. Int Urol Nephrol 2011; 43: 7639.

11. Stein DM, Thum DJ, Barbagli G, Kulkarni G, Sansalone S, Pardeshi A, et al. A geographic analysis of male urethral stricture aetiology and location. BJU Int 2013; 112: 830-4.

12. Wood DN, Andrich DE Greenwell TJ, Mundy AR. Standing the test of time: the long-term results of urethroplasty. World J Urol 2006; 24: 250-4.

13. Schwentner C, Seibold J, Colleselli D, Alloussi SH, Schilling D, Sievert KD, et al. Dorsal Onlay Skin Graft Urethroplasty in Patients Older Than 65 Years. Urology 2010; 76: 465-70.

14. Lumen N, Hoebeke P, Willemsen P, De Troyer B, Pieters R, Oosterlinck W. Etiology of urethral stricture disease in the 21st century. J Urol 2009; 182: 983-7.

15. Zumrutbas AE, Ozlulerden Y, Celen S, Kucuker K, Aybek Z. The outcomes of Kulkarni's one-stage oral mucosa graft urethroplasty in patients with panurethral stricture: a single centre experience. World J Urol 2020; 38: 175-81.

16. Santucci RA, Joyce GF, Wise M. Male Urethral Stricture Disease. J Urol 2007; 177: 1667-74.

17. Santucci RA, McAninch JW, Mario LA, Rajpurkar A, Chopra AK, Miller KS, et al. Urethroplasty in patients older than 65 years: indications, results, outcomes and suggested treatment modifications. J Urol 2004; 172: 201-3.

18. Mundy RA, Andrich DE. Urethral Strictures, BJU Int 2011; 107: 6-26.

19. Albers $P$, Fichtner J, Brühl P, Müller SC. Long-term results of internal urethrotomy. J Urol 1996; 156: 1611-4.

20. Al-Taweel W, Seyam R. Visual internal urethrotomy for adult male urethral stricture has poor long-term results. Adv Urol 2015; 2015: 656459.

21. Barbagli G, Lazzeri M. Urethral reconstruction. Curr Opin Urol 2006; 16: 391-5.

22. Andrich DE, Mundy AR. What is the best technique for urethroplasty? Eur Urol 2008; 54: 1031-41.

23. Barbagli G, Palminteri E, Lazzeri M, Guazzoni G. Anterior urethral strictures. BJU Int 2003; 92: 497-505.

24. Kulkarni S, Barbagli G, Sansalone S, Lazzeri M. One-sided anterior urethroplasty: a new dorsal onlay graft technique. BJU Int 2009; 104: 1150-5.

25. Barbagli G, Morgia G, Lazzeri M. Retrospective outcome analysis of onestage penile urethroplasty using a flap or graft in a homogeneous series of patients. BJU Int 2008; 102: 853-60.

26. Şahin $M$, Kutlu $M$. Yaşlı kardiyovasküler hastalarda sık görülen komorbiteler. Turk Kardiyol Dern Ars 2017; 45(Suppl 59): 13-6.

27. Blaschko SD, Harris CR, Zaid UB, Gaither T, Chu C, Alwaal A, et al. Trends, utilization, and immediate perioperative complications of urethroplasty in the United States: data from the national inpatient sample 2000-2010. Urology 2015; 85: 1190-4.

28. Chapman D, Kinnaird A, Rourke K. Independent predictors of stricture recurrence following urethroplasty for isolated bulbar urethral strictures. J Urol 2017; 198: 1107-12.

29. Isidori AM, Buvat J, Corona G, Goldstein I, Jannini EA, Lenzi A, et al A critical analysis of the role of testosterone in erectile function: from pathophysiology to treatment-a systematic review. Eur Urol 2014; 65: 99-112.

30. Christe N, Meier CA. Hypotestosteronaemia in the aging male: should we treat it? Swiss Med Wkly 2015; 145: w14216.

31. Ayyildiz SN. The importance of measuring the uncertainty of secondgeneration total testosterone analysis, Int J Med Biochem 2018; 1: 34-9.

32. Corona G, Maggi M. Perspective: Regulatory agencies' changes to testosterone product labeling. J Sex Med 2015; 12: 1690-3. 
33. Ho CH, Fan $\mathrm{CK}$, Yu HJ, Wu CC, Chen KC, Liu SP, et al. Testosterone suppresses uropathogenic Escherichia coli invasion and colonization within prostate cells and inhibits inflammatory responses through JAK/ STAT-1 signaling pathway. PLoS One 2007; 12: e0180244.

34. Malkin C, Pugh P, Jones R, Kapoor D, Channer K, Jones H. The effect of testosterone replacement on endogenous inflammatory cytokines and lipid profiles in hypogonadal men. J Clin Endocrinol Metab 2004; 89: 3313-8.

35. Andrich DE, Mundy A R. Urethral strictures and their surgical treatment. BJU Int 2000; 86: 571.

36. Andrich DE, Mundy AR. What's new in urethroplasty? Curr Opin Urol 2011; 21: 455-60

37. Andrich DE, Mundy AR. What is the best technique for urethroplasty? Eur Urol 2008; 54: 1031-41.

38. Andrich DE, Dunglison N, Greenwell TJ, Mundy AR. The long-term results of urethroplasty. J Urol 2003; 170: 90-2.

39. Markiewicz MR, Lukose MA, Margarone JE 3rd, Barbagli G, Miller KS, Chuang SK. The oral mucosa graft: a systematic review. J Urol 2007; 178: 387-94.

40. Splieth $\mathrm{CH}$, Sumnig W, Bessel F, John U, Kocher T. Prevalence of oral mucosal lesions in a representative population. Quintessence Int 2007; 38: 23-96.

41. Sinha RJ, Singh V, Sankhwar SN, Dalela D. Donor site morbidity in oral mucosa graft urethroplasty: implications of tobacco consumption. BMC Urol 2009; 9: 15

42. Manoj B, Sanjeev N, Pandurang PN, Jaideep M, Ravi M. Postauricular skin as an alternative to oral mucosa for anterior onlay graft urethroplasty: a preliminary experience in patients with oral mucosa changes. Urology 2009; 74: 345-8

43. Jayanthi V, Probert CS, Sher KS, Mayberry JF. Oral submucosal fibrosis: a preventable disease. Gut 1992; 33: 4-6.

44. McAninch JW. Reconstruction of extensive urethral strictures: circular fasciocutaneous penile flap. J Urol 1993; 149: 488-91.

45. Morey AF, Tran LK, Zinman LM. Q-flap reconstruction of panurethral strictures. BJU Int 2000; 86: 1039-42.

46. Spencer J, Blakely S, Daugherty M, Angulo JC, Martins F, Venkatesan $\mathrm{K}$, et al. Clinical and patient-reported outcomes of 1-sided anterior urethroplasty for long-segment or panurethral strictures. Urology 2018; 111: 208-13.

47. Santucci RA, Mario LA, McAninch JW. Anastomotic urethroplasty for bulbar urethral sticture: analysis of 168 patients. J Urol 2002; 167: 1715-9.

48. Barbagli G, Palmintieri E, Lazzeri M. Dorsal only techniques for urethroplasty. Urol Clin North Am 2002; 29: 389-95.

49. Barbagli G, Montorsi F, Guazzoni G, Larcher A, Fossati N, Sansalone S, et al. Ventral oral mucosal onlay graft ureth-roplasty in nontraumatic bulbar urethral strictures: Surgical technique and multivariate analysis of results in 214 patients. Eur Urol 2013; 64: 440-7.

50. Santucci RA, Mario LA, McAninch JW. Anastomotic urethroplasty for bulbar urethral sticture: analysis of 168 patients. J Urol 2002; 167: 1715-19.

51. Webster GD, Peterson AC. Simple perineal and elaborated perineal posterior urethroplasty. Arab J Urol 2015; 13: 17-23.
52. Soave A, Kluth L, Dahlem R, Rohwer A, Rink M, Reiss P, et al. Outcome of buccal mucosa graft urethroplasty: a detailed analysis of success, morbidity and quality of life in a contemporary patient cohort at a referral center. BMC Urol 2019; 19: 18.

53. Meeks JJ, Erickson BA, Granieri MA, Gonzalez CM. Stricture recurrence after urethroplasty: a systematic review. J Urol 2009; 182: 1266-70.

54. Mundy AR. Urethroplasty for posterior urethral strictures. Br J Urol 1996; 78: 243.

55. Blair SL, Schwarz RE. Advanced age does not contribute to increased risks or poor outcome after major abdominal operations. Am Surg 2001; 67: 1123-7.

56. Gumus E, Kendirci M, Horasanli, K, Tanriverdi O, Gidemez G, Miroglu C. Neurapraxic complications in operations performed in the lithotomy position. World J Urol 2002; 20: 68-71.

57. Wood DN, Allen SE, Andrich DE, Greenwell TJ, Mundy AR. The morbidity of buccal mucosal graft harvest for urethroplasty and the effect of nonclosure of the graft harvest site on postoperative pain. J Urol 2004; 172: 580-3.

58. Alsikafi NF, Eisenberg M, McAninch JW. Long-term outcomes of penile skin graft versus buccal mucosal graft for substitution urethroplasty of the anterior urethra. J Urol 2005; 173: 87.

59. Akgül M, Kaya $C$. Tekrarlayan bulbar üretra darlıkları: güncel yaklaşım. Kontinans Nöroürol Bült 2015; 2: 93-7.

60. Mangera A, Patterson JM, Chapple CR. A systematic review of graft augmentation urethroplasty techniques for the treatment of anterior urethral strictures. Eur Urol 2011; 59: 797-814.

61. Mangir N, Wilson KJ, Osman NI, Chapple CR. Current state of urethral tissue engineering. Curr Opin Urol 2019; 29: 385-93.

62. Şimşek A, Şeker KG, Kadıoğlu A. Üretra darlıklarında tanı, tedavi ve takip protokollari kılavuzu. 2016; pp: 1-22.

63. Wicke C, Bachinger A, Coerper S, Beckert S, Witte MB, Königsrainer A. Aging influences wound healing in patients with chronic lower extremity wounds treated in aspecialized wound care center. Wound Repair Regen 2009; 17: 25-33.

64. Acar K, Aygin D. Yaşlılarda yara gelişimi risk faktorleri, onleme ve bakım yaklaşımları. Yoğun Bakım Hemş Derg 2015; 19: 54-9.

65. Gosain A, DiPietro LA. Aging and wound healing. World J Surg 2004; 28: 321-6.

66. Tandara AA, Mustoe TA. Oxygen in wound healing-more than a nutrient. World J Surg 2004; 28: 294-300.

67. Kutluay Köklü AH, Uğar Çangal DA. Yara iyileşmesini etkileyen faktörler içerisinde beslenmenin yeri. Atatürk Üniv Diş Hek Fak Derg 2013; 7: 13541. 